\title{
Faktor-Faktor yang Berhubungan dengan Tingkat Pengetahuan Dokter Jaga IGD tentang Penatalaksanaan Kasus Henti Jantung di Rumah Sakit Tipe C se-Sumatera Barat
}

\author{
Sakinah $^{1}$, M. Fadil ${ }^{2}$, Firdawati ${ }^{3}$
}

\begin{abstract}
Abstrak
Ada beberapa faktor yang mempengaruhi tingkat pengetahuan dokter jaga IGD diataranya usia, lama kerja di IGD, sertifikat ACLS, masa berlakunya dan lulusan. Tujuan penelitian ini adalah untuk mengetahui faktor-faktor yang berhubungan dengan tingkat pengetahuan dokter jaga IGD tentang penatalaksanaan kasus henti jantung di rumah sakit tipe C di Sumatera Barat. Jenis penelitian ini adalah studi analitik bivariat dengan pendekatan survei dan menggunakan uji Chi-square untuk melihat hubungan antar variabel. Pengambilan sampel dilakukan dengan metode cluster sampling pada beberapa kota dan kabupaten yang dianggap dapat mewakili wilayah Sumatera Barat. Sampel pada penelitian ini berjumlah 44 orang yang dipilih berdasarkan kriteria inklusi dan ekslusi. Penelitian ini menggunakan kuesioner yang sudah divalidasi untuk kemudian diisi oleh responden. Hasil penelitian didapatkan bahwa umur, masa kerja, kepemilikan sertifikat ACLS, masa berlakunya serta lulusan masing-masing memilki nilai $p$ sebesar 0,853 ( $p>0,05), 0,077(p>0,05), 0,005(p<0,05), 0,032(p<0,05), 0,002(p<0,05)$. Simpulan penelitian adalah ada beberapa faktor yang mempengaruhi tingkat pengetahuan dokter jaga IGD dalam penatalaksanaan kasus henti jantung antara lain kepemilikan sertifikat ACLS, masa berlaku ACLS dan lulusan perguruan tinggi sebelumnya.
\end{abstract}

Kata kunci: henti jantung, tingkat pengetahuan, dokter jaga IGD, faktor yang mempengaruhi, rumah sakit tipe $C$

\begin{abstract}
There are some factors that affects the knowledge level of doctor on duty in emergency room, which are age, how long the doctor has been working in emergency room is, ACLS certificate, validation time of the certificate and the college where the doctor have been studied before to become a doctor. The objective of this study was to understand the factors related to the knowledge level of doctor on duty in emergency room of type $C$ hospitals in West Sumatera about the cardiac arrest treatment.This research was a bivariate analysis research using survey approachment and Chi-square test to find out the correlation of the variables. Cluster sampling method used in several hospitals in some cities and regencies representing a whole area of West Sumatera. There were 44 chosen samples based on inclusion and exclusion criterias. This research was conducted using validated questionnaire filled by the respondents. This research found out that age, how long the doctor has been working, ACLS certificate, validation time of the certificate and the college where the doctor hd been studied before to become a doctor, each of those shows $0,853$ ( $p>0,05), 0,077$ ( $p>0,05), 0,005(p<0,05), 0,032(p<0,05), 0,002(p<0,05)$ for $p$-value.The conclussion of this research is there are some factors related to the knowledge level of doctor on duty in emergency room in order to treat a cardiac arrest case, which are ACLS certificate, validation time of the certificate, and the college where the doctor have been studied before to become a doctor.
\end{abstract}

Keywords: cardiac arrest, knowledge level, doctor on duty of emergency room, type C hospital 
Affiliasi penulis: 1. Prodi Kedokteran Fakultas Kedokteran Universitas Andalas Padang (FK Unand), 2. Bagian Jantung dan Pembuluh Darah FK Unand, 3. Bagian IImu Kesehatan Masyarakat FK Unand

Korespondensi: Sakinah, email: sakinah.030996@gmail.com Telp: 081364382876

\section{PENDAHULUAN}

Kasus henti jantung merupakan penyebab kematian utama yang banyak ditemukan di masyarakat sampai saat ini baik itu di negara maju ataupun negara berkembang seperti Indonesia. Sebanyak $60 \%$ kematian pada penderita dewasa yang mengalami penyakit jantung koroner disebabkan oleh henti jantung. ${ }^{1}$ Kasus henti jantung jika tidak mendapatkan penanganan yang baik dari tenaga medis dapat mengakibatkan kematian. $^{2} \mathrm{Di}$ berbagai belahan dunia, prevalensi kasus cardiac arrest cukup tinggi. Di Amerika dan Kanada angka kejadian cardiac arrest mencapai 350.000 kasus per-tahun. ${ }^{3}$

Menurut Goldbelger (2012) lima dari 1000 pasien yang dirawat di rumah sakit di beberapa negara berkembang diperkirakan mengalami henti jantung dan kurang dari $20 \%$ dari jumlah pasien tersebut tidak mampu bertahan hingga keluar dari rumah sakit. ${ }^{4}$ Berdasarkan data Departemen Kesehatan tahun 2006 prevalensi penderita henti jantung di Indonesia tiap tahunnya belum didapatkan data yang jelas, namun diperkirakan sekitar 10 ribu warga. Ini berarti 30 orang per hari. Dan data di ruang perawatan koroner intensif Rumah Sakit Cipto Mangunkusuma tahun 2006, menunjukkan terdapat 6,7\% pasien mengalami atrial fibrilasi, yang merupakan kelainan irama jantung yang bisa menyebabkan henti jantung. ${ }^{5}$

Berdasarkan American Heart Association henti jantung adalah hilangnya fungsi jantung pada seseorang secara tiba-tiba yang mungkin atau yang tidak mungkin telah didiagnosis penyakit jantung. ${ }^{3}$ Tatalaksana atau tindakan yang dapat diberikan pada kasus henti jantung untuk dapat bertahan hidup adalah aktifkan chain of survival atau rantai kelangsungan hidup yaitu tindakan saat pertama terjadi henti jantung sampai perawatan setelah terjadi henti jantung berdasarkan American Heart Association (AHA) 2010

.$^{3}$ Rantai kelangsungan hidup meliputi Basic Cardiac Life Support (BCLS) merupakan bantuan hidup jantung dasar dan Advanced Cardiovascular Life Support
(ACLS) merupakan bantuan hidup jantung lanjut yang dapat diberikan pada pasien henti jantung. ${ }^{6}$

Basic Cardiac Life Support (BCLS) akan memberikan hasil yang paling baik jika dilakukan dalam lima menit pertama saat pasien diketahui tidak sadarkan diri. ${ }^{2}$ Dan tatalaksana bantuan hidup jantung lanjut / Advanced Cardiac Life Support (ACLS) juga merupakan komponen penting, karena pasien henti jantung yang kembali memiliki sirkulasi spontan tetap memiliki resiko kematian yang tinggi. Kematian paling banyak terjadi dalam 24 jam pertama. ${ }^{1}$ Sehingga diperlukannya perawatan yang lebih lanjut dan khusus seperti obat atau tatalaksana faktor penyebab henti jantung yang mendasari.

Dokter jaga IGD adalah seorang dokter umum yang masih aktif maupun honorer atau volunteer yang ditetapkan oleh surat perintah kepala rumah sakit dan bertanggung jawab dalam pelayanan medis di IGD selama dan atau diluar jam kerja. ${ }^{7}$ Dokter jaga IGD harus mempunyai STR dan SIP untuk bisa menjalankan praktik kedokteran di tempatnya bekerja. Sekarang dokter jaga IGD juga sangat dianjurkan bahkan diwajibkan untuk mengikuti pelatihan dan mempunyai sertifikat ACLS sebagai bekal untuk bertindak lebih baik di IGD. Menurut Undang-Undang Nomor 36 tahun 2014 tentang Tenaga Kesehatan, setiap tenaga kesehatan yang menjalankan praktik, yang dalam ini termasuk dokter jaga IGD, berkewajiban untuk mematuhi Standar Profesi, Standar Pelayanan Profesi, dan Standar Prosedur Operasional. Standar Profesi dan Standar Pelayanan Profesi ditetapkan oleh organisasi profesi bidang kesehatan dan disahkan oleh menteri, sedangkan Standar Prosedur Operasional ditetapkan oleh fasilitas pelayanan kesehatan. ${ }^{8}$

Instalasi Gawat Darurat (IGD) adalah unit rumah sakit yang memberikan pelayanan pertama kepada pasien. Unit ini dipimpin oleh seorang dokter jaga dengan tenaga dokter ahli dan berpengalaman dalam menangani PGD (Pelayanan Gawat Darurat), yang kemudian jika dibutuhkan akan merujuk pasien kepada dokter spesialis tertentu atau rumah sakit yang di tingkat yang lebih tinggi. $^{9}$ Prosedur pelayanan di IGD merupakan kunci awal pelayanan petugas rumah sakit dalam melayani pasien. Kualitas pelayanan ditentukan oleh baik atau tidaknya sikap, 
tanggung jawab dan kesigapan petugas dalam memberikan pelayanan kepada pasien. ${ }^{10}$ Oleh karena itu sangat penting untuk meningkatkan kemampuan dokter terutama dokter jaga IGD dalam penanganan cardiac arrest yang salah satunya meliputi pengetahuan dalam penatalaksanaan henti jantung di Rumah Sakit

Rumah Sakit Tipe C merupakan sarana pelayanan kesehatan umum tingkat kabupaten/kota yang mempunyai fasilitas dan kemampuan pelayanan medis 4 (empat) spesialistik dasar dan 4 (empat) spesialistik penunjang. ${ }^{11}$ Keempat pelayanan medis spesialistik dasar ini meliputi IImu Penyakit Dalam, IImu Kesehatan Anak, Bedah, serta Obstetri dan Ginekologi. ${ }^{[12]}$ Sehingga penulis berasumsi bahwa perlunya pengetahuan yang tepat dalam penanganan kasus ini oleh dokter jaga IGD di Rumah Sakit tersebut dikarenakan tidak adanya spesialistik kardiovaskular dalam pelayanan spesialistik dasar yang dimiliki rumah sakit tipe $\mathrm{C}$ ini.

\section{METODE}

Jenis penelitian ini adalah analitik dengan pendekatan survei untuk mengetahui faktor-faktor yang mempengaruhi tingkat pengetahuan dokter jaga IGD tentang penatalaksanaan kasus henti jantung di rumah sakit tipe $\mathrm{C}$ se-Sumatera Barat.Penelitian dilakukan dari bulan Oktober 2017 sampai Maret 2018 di rumah sakit tipe $\mathrm{C}$ di Sumatera Barat yang diyakini dapat mewakili keseluruhan rumah sakit tipe $\mathrm{C}$ yang ada di Sumatera Barat.

Populasi penelitian ini adalah semua dokter jaga IGD rumah sakit tipe $C$ se-Sumatera Barat. Sampel penelitian yang dipilih adalah dokter jaga IGD rumah sakit tipe $C$ di Sumatera Barat yang dianggap dapat mewakili populasi penelitian yang memenuhi kriteria inklusi dan eksklusi. Pengambilan sampel dilakukan dengan metode cluster sampling, yaitu dengan cara mengambil sampel berdasarkan wilayah atau lokasi populasi oleh karena objek yang diteliti sangat luas dan jarak dan biaya yang terbatas. Peneliti mengambil 5 kota dan 5 kabupaten di Sumatera Barat sebagai wilayah dari cluster, yang dalam hal ini adalah rumah sakit tipe $C$, yang dapat mewakili wilayah Sumatera Barat untuk kemudian diambil sampel berupa dokter jaga IGD di rumah sakit tipe $C$ yang terdapat di wilayah tersebut. Kriteria inklusi subjek: Dokter jaga IGD bukan spesialis di rumah sakit umum tipe C wilayah Sumatera Barat yang terpilih melalui metode pengambilan sampel yang digunakan dan bersedia menjadi responden.

Data diperoleh dari kuisioner yang telah diisi oleh responden yang kemudian disajikan dengan mendistribusikan melalui analisis univariat dan bivariat. Analisis univariat dilakukan terhadap usia, lama kerja di IGD, asal perguruan tinggi, dan keikutsertaan dalam pelatihan ACLS (Advanced Cardiac Life Support) serta masa berlaku sertifikatnya.

\section{HASIL}

Tabel 1. Karakteristik dokter jaga IGD rumah sakit tipe C di Sumatera Barat

\begin{tabular}{lcc}
\hline \multicolumn{1}{c}{ Karakteristik } & $\mathbf{f}(\mathbf{n}=44)$ & $\%$ \\
\hline Umur & 12 & 27,3 \\
$\leq 25$ tahun (remaja akhir) & 32 & 72,7 \\
$>25$ tahun (dewasa awal) & & \\
Jenis Kelamin & 18 & 40,9 \\
$\quad$ Laki-laki & 26 & 59,1 \\
$\quad$ Perempuan & & \\
Lama kerja di IGD & 38 & 86,4 \\
$\quad \leq 3$ tahun (baru) & 6 & 13,5 \\
$\quad>3$ tahun (lama) & & \\
Sertifikat ACLS & 33 & 75,0 \\
$\quad$ Ada & 11 & 25,0 \\
Tidak & & \\
Masa berlaku ACLS (n=33) & 28 & 84,8 \\
$\quad$ Masih berlaku & 5 & 15,2 \\
Tidak berlaku & & \\
Lulusan Perguruan Tinggi & 36 & 18,2 \\
Negeri & 8 & \\
Swasta & & \\
\hline
\end{tabular}

Berdasarkan Tabel 1 didapatkan bahwa, terdapat $72,7 \%$ responden berumur $>25$ tahun atau tergolong usia dewasa muda, 59,1\% responden berjenis kelamin perempuan. Dilihat dari lama kerja IGD mayoritas responden (86,4\%) adalah kurang dari 3 tahun dan tergolong masih baru. Sebanyak $75 \%$ responden telah memiliki sertifikat ACLS dan 63,6\% responden memiliki serifikat yang masih berlaku. Sedangkan dilihat dari lulusan perguruan tinggi mayoritas responden merupakan lulusan perguruan tinggi negeri $(81,8 \%)$. 
Tabel 2. Tingkat pengetahuan dokter jaga IGD rumah sakit tipe $\mathrm{C}$ di Sumatera Barat

\begin{tabular}{ccc}
\hline Tingkat pengetahuan & $\mathrm{f}(\mathrm{n}=4 \mathrm{H})$ & $\%$ \\
Baik & 25 & 56,8 \\
Cukup & 13 & 29,5 \\
Buruk & 6 & 13,6 \\
Total & 44 & 100 \\
\hline
\end{tabular}

Pada Tabel 2 mayoritas responden memiliki tingkat pengetahuan mengenai tatalaksana henti jantung berkategori baik yaitu sebesar $56,8 \%$.

Tabel 3. Hubungan umur dengan tingkat pengetahuan dokter jaga IGD tentang tatalaksana henti jantung

\begin{tabular}{|c|c|c|c|c|c|}
\hline \multirow{3}{*}{ Umur } & \multicolumn{3}{|c|}{ Tingkat Pengetahuan } & \multirow{3}{*}{$\mathrm{f}$} & \multirow{3}{*}{$\mathrm{p}$-value } \\
\hline & Baik & Cukup & Buruk & & \\
\hline & f $\%$ & $\%$ & f $\%$ & & \\
\hline$\leq 25$ tahun & 24 & 30,8 & $\begin{array}{ll}2 & 33,3\end{array}$ & 12 & 0,849 \\
\hline$>25$ tahun & 76 & 69,2 & 66,7 & 32 & \\
\hline Total & $25 \quad 100$ & \begin{tabular}{l|l}
13 & 100
\end{tabular} & 6100 & 44 & \\
\hline
\end{tabular}

Berdasarkan Tabel 3, hasil uji statistik diperoleh nilai $p=0,849(p>0,05)$. Berdasarkan hasil tersebut dapat disimpulkan secara statistik bahwa usia tidak memilki hubungan yang bermakna dengan tingkat pengetahuan. Dengan perbandingan tingkat pengetahuan yang buruk pada usia sama dengan atau kurang dari 25 tahun dan lebih dari 25 tahun adalah $33,3 \%$ berbanding $66,7 \%$. Sedangkan untuk kategori tingkat pengetahuan cukup, perbandingan antara remaja awal dengan dewasa awal adalah 30,8\% berbanding 69,2\%. Dan kategori baik memiliki perbandingan $24 \%$ dan $76 \%$ untuk kategori usia tersebut.

Tabel 4. Hubungan lama kerja dengan tingkat pengetahuan

\begin{tabular}{|c|c|c|c|c|c|c|c|c|}
\hline \multirow{3}{*}{ Lama Kerja } & \multicolumn{6}{|c|}{ Tingkat Pengetahuan } & \multirow{2}{*}{ Total } & \multirow{3}{*}{ p-value } \\
\hline & \multicolumn{2}{|c|}{ Baik } & \multicolumn{2}{|c|}{ Cukup } & \multicolumn{2}{|c|}{ Buruk } & & \\
\hline & $f$ & $\%$ & $\mathrm{f}$ & $\%$ & $f$ & $\%$ & $f$ & \\
\hline$\leq 3$ tahun & 24 & 96 & 9 & 69,2 & 5 & 83,3 & 38 & 0,072 \\
\hline$>3$ tahun & 1 & 4 & 4 & 30,8 & 1 & 16,7 & 6 & \\
\hline Total & & 100 & 13 & 100 & 6 & 100 & 44 & \\
\hline
\end{tabular}

Pada Tabel 4 terlihat hasil uji statistik diperoleh nilai $p=0,072(p>0,05)$. Berdasarkan hasil tersebut dapat disimpulkan secara statistik bahwa lama kerja tidak memilki hubungan yang bermakna terhadap tingkat pengetahuan. Tingkat pengetahuan yang buruk pada masa kerja sama dengan atau kurang dari 3 tahun dengan lebih dari tiga tahun memiliki perbandingan $83,3 \%$ berbanding $16,7 \%$, kategori cukup memiliki perbandingan 69,2\% berbanding $30,8 \%$ dan kategori baik memiliki perbandingan $96 \%$ berbanding $4 \%$.

Tabel 5. Hubungan sertifikat ACLS dengan tingkat pengetahuan

\begin{tabular}{|c|c|c|c|c|c|c|}
\hline \multirow{3}{*}{$\begin{array}{l}\text { Sertifikat } \\
\text { ACLS }\end{array}$} & \multicolumn{4}{|c|}{ Tingkat Pengetahuan } & \multirow{2}{*}{ Total } & \multirow{3}{*}{$\mathrm{p}$-value } \\
\hline & Baik & & kup & Buruk & & \\
\hline & f $\%$ & $f$ & $\%$ & f $\%$ & $f$ & \\
\hline Ada & 92 & 8 & 61,5 & $\begin{array}{ll}2 & 33,3\end{array}$ & 33 & 0,005 \\
\hline Tidak & 2 & 5 & 38,5 & 66,7 & 11 & \\
\hline Total & $25 \quad 100$ & 13 & 100 & $\begin{array}{ll}6 & 100\end{array}$ & 44 & \\
\hline
\end{tabular}

Pada Tabel 5 terlihat hasil uji statistik diperoleh nilai $p=0,005(p<0,05)$. Berdasarkan hasil tersebut dapat disimpulkan secara statistik bahwa sertifikat ACLS memilki hubungan yang bermakna dengan tingkat pengetahuan. Tingkat pengetahuan yang buruk pada yang memiliki sertifikat ACLS dengan yang tidak memiliki sertifikat ACLS memiliki perbandingan 33,3\% berbanding 66,7\%, kategori cukup memiliki perbandingan $61,5 \%$ berbanding $38,5 \%$, dan kategori baik memiliki perbandingan $92 \%$ berbanding $8 \%$.

Tabel 6. Hubungan masa berlaku ACLS dengan tingkat pengetahuan

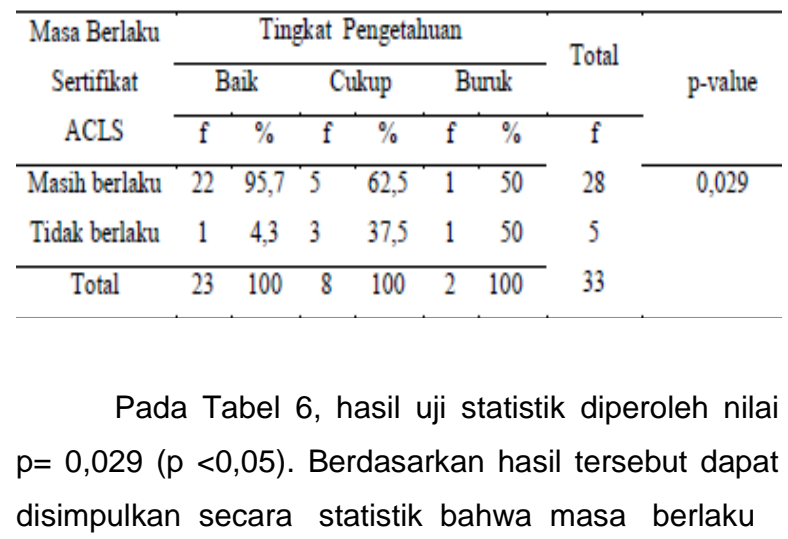


sertifikat ACLS memilki hubungan yang bermakna dengan tingkat pengetahuan. Tingkat pengetahuan yang buruk pada responden yang sertifikat ACLSnya masih berlaku dengan yang tidak lagi berlaku memiliki perbandingan $50 \%$ berbanding $50 \%$, kategori cukup memiliki perbandingan $62,5 \%$ berbanding $37,5 \%$ dan kategori baik memiliki 95,7\% berbanding 4,3\%.

Tabel 7. Hubungan lulusan perguruan tinggi dengan tingkat pengetahuan

\begin{tabular}{|c|c|c|c|c|c|c|c|}
\hline \multirow{3}{*}{$\begin{array}{c}\text { Lulusan } \\
\text { Perguruan } \\
\text { Tinggi }\end{array}$} & \multicolumn{5}{|c|}{ Tingkat Pengetahuan } & \multirow{2}{*}{ Total } & \multirow{3}{*}{$\mathrm{p}$-value } \\
\hline & Baik & \multicolumn{2}{|c|}{ Cukup } & \multicolumn{2}{|c|}{ Buruk } & & \\
\hline & $\%$ & $\mathrm{f}$ & $\%$ & $f$ & $\%$ & $f$ & \\
\hline Negeri & 24 & 10 & 76,9 & 2 & 33,3 & 36 & 0,001 \\
\hline Swasta & 1 & 3 & 23,1 & 4 & 66,7 & 8 & \\
\hline Total & $25 \quad 100$ & 13 & 100 & 6 & 100 & 44 & \\
\hline
\end{tabular}

Berdasarkan Tabel 7, hasil uji statistik diperoleh nilai $p=0,001 \quad(p<0,05)$. Berdasarkan hasil tersebut dapat disimpulkan secara statistik bahwa lulusan perguruan tinggi memilki hubungan yang bermakna dengan tingkat pengetahuan.Tingkat pengetahuan yang buruk pada responden yang lulusan perguruan tinggi negeri dengan lulusan perguruan tinggi swasta memiliki perbandingan $33,3 \%$ berbanding $66,7 \%$, kategori cukup memiliki perbandingan 76,9\% berbanding 23,1\%, dan kategori baik memiliki perbandingan $96 \%$ berbanding $4 \%$.

\section{PEMBAHASAN}

\section{Karakteristik rerponden}

Hasil penelitian menunjukkan bahwa responden lebih banyak berumur lebih dari 25 tahun. Hal ini sesuai dengan kepustakaan yang menyatakan bahwa pada umur di atas 25 tahun, atau dapat dikatakan ketika seseorang lebih cukup umur, tingkat kemampuan dan kekuatannya akan lebih matang dalam berpikir dan bekerja. Seseorang yang lebih dewasa mempunyai kecenderungan akan lebih dipercaya daripada orang yang belum cukup tinggi kedewasaannya. Hal ini sebagai akibat dari pengalaman kematangan jiwanya. ${ }^{13}$ Penelitian ini menunjukkan bahwa perbedaan jumlah responden laki-laki dan perempuan dalam penelitian ini tidak berbeda jauh, yaitu sebesar $41 \%$ berbanding $59 \%$.
Terdapat sebanyak $86 \%$ dokter jaga IGD di rumah sakit tipe $\mathrm{C}$ di Sumatera Barat baru bekerja selama tiga tahun atau kurang dari tiga tahun, dan hanya $14 \%$ yang bekerja lebih dari tiga tahun. Hal ini menunjukkan bahwa lebih banyak dokter jaga IGD yang dapat dikategorikan menjadi baru bekerja daripada yang sudah lama bekerja. ${ }^{14}$

Lama kerja di IGD akan mempengaruhi pengalaman seorang dokter jaga dalam menangani kasus henti jantung. Semakin lama seorang dokter jaga bekerja, kemungkinan untuk menangani kasus henti jantung akan semakin meningkat dikarenakan akan semakin sering kasus tersebut dijumpai di rumah sakit. Semakin sering dokter tersebut menangani kasus henti jantung, maka pengetahuannya tentang penatalaksanaan kasus tersebut akan semakin baik. Hal ini sesuai dengan pendapat yang dikemukakan oleh Notoadmojo bahwa pengalaman merupakan salah satu faktor yang mempengaruhi pengetahuan seseorang. ${ }^{15}$

Hasil penelitian ini juga menunjukkan bahwa $75 \%$ dari responden sudah memilki sertifikat ACLS yang berati dokter jaga tersebut telah mengikuti pelatihan mengenai ACLS sebelumnya. Dan hanya $25 \%$ dari responden yang belum memilki sertifikat ACLS. Pelatihan akan mempengaruhi tingkat pengetahuan seseorang. Hal ini sesuai dengan yang dikemukakan oleh Bart bahwa pelatihan merupakan upaya meningkatkan pengetahuan, mengubah perilaku, dan mengembangkan keterampilan. ${ }^{16}$

Adapun dari seluruh responden yang telah memilki sertifikat ACLS, $85 \%$ diantaranya memiliki sertifikat yang masih berlaku, yaitu sertifikat yang waktunya masih belum lebih dari tiga tahun sejak sertifikat tersebut didapatkan dan $15 \%$ dari responden memilki sertifikat yang sudah tidak berlaku lagi karena sudah lewat dari tiga tahun.

Penelitian ini menunjukkan bahwa $82 \%$ dari responden berasal dari perguruan tinggi negeri di Indonesia dan $15 \%$ dari responden berasal dari perguruan tinggi swasta di Indonesia.

\section{Tingkat Pengetahuan Dokter Jaga IGD tentang Penatalaksanaan Kasus Henti Jantung}

Hasil penelitian menunjukkan bahwa $56,8 \%$ dari responden memiliki tingkat pengetahuan yang 
baik, 29,5\% berpengetahuan cukup, dan 13,6\% memiliki tingkat pengetahuan yang buruk. Hal ini berarti lebih dari separuh responden tahu bagaimana penatalaksanaan yang baik untuk kasus henti jantung, dimulai dari pengetahuan dalam mendiagnosis hingga memberikan perawatan pasca henti jantung kepada pasien.

Pengetahuan dapat mempengaruhi seorang dokter secara alamiah dan mendasar dalam mengambil keputusan mengenai hal yang harus segera dilakukan serta yang tidak boleh dilakukan. Pengetahuan yang baik dari seorang dokter jaga IGD akan mempengaruhi dokter tersebut dalam mengambil keputusan untuk menatalaksana pasien. Pada akhirnya, hal itu juga akan mempengaruhi prognosis dari pasien tersebut. Oleh karena itu, upaya untuk meningkatkan pengetahuan dokter jaga IGD di setiap rumah sakit sangat penting dilakukan dengan baik dan sungguh-sungguh.

\section{Hubungan umur dengan tingkat pengetahuan} dokter jaga IGD tentang tatalaksana henti jantung

Pada penelitian ini terlihat pengaruh umur tidak signifikan terhadap tingkat pengetahuan dokter jaga IGD tentang penatalaksanaan kasus henti jantung. Berdasarkan tabel 3 , terlihat bahwa nilai $p=0,853$ ( $p>0,05)$. Responden dikelompokkan ke dalam dua kategori umur, yaitu 17-25 tahun dan 26-35 tahun, yang tergolong remaja akhir dan dewasa awal sesuai dengan kategori umur yang dikeluarkan oleh Departemen Kesehatan RI pada tahun 2009. ${ }^{17}$ Pada kategori remaja akhir, responden berjumlah 12 orang dengan rincian yang memiliki tingkat pengetahuan baik sebesar 50\%, cukup sebesar 33,3\%, dan buruk sebesar $16,7 \%$. Sedangkan pada kategori dewasa awal, responden berjumlah 32 orang dengan tingkat pengetahuan baik $(59,4 \%)$, cukup $(29,5 \%)$, dan buruk (12,5\%).

Hal ini berbeda dengan pendapat yang diungkapkan oleh Notoatmodjo yang menyatakan bahwa makin tua umur seseorang maka prosesproses perkembangan mentalnya bertambah baik walaupun tidak secepat seperti ketika berumur belasan tahun. ${ }^{15}$ Diungkapkan juga oleh Knoers dan Hadinoto pada tahun 2004 bahwa semakin tua usia seseorang tingkat kemampuan dan kekuatannya dalam berfikir dan bekerja akan semakin baik. ${ }^{13}$ Sehingga dapat disimpulkan bahwa bertambahnya umur seseorang dapat berpengaruh pada pertambahan pengetahuan yang diperolehnya

Hasil penelitian ini sejalan dengan penelitian yang telah dilakukan oleh Ingga Ifada dari Fakultas Kedokteran Diponegoro pada tahun 2010 bahwa tidak terdapat hubungan yang bermakna antara umur dengan tingkat pengetahuan. ${ }^{18} \mathrm{Hal}$ ini didukung oleh Verner dan Davison dalam Maulana (2007) bahwa ada beberapa faktor fisik yang dapat menghambat proses belajar pada orang dewasa sehingga membuat penurunan pada suatu waktu dalam kekuatan berfikir dan bekerja. ${ }^{22}$

Ketiadaan hubungan antara umur dengan tingkat pengetahuan dokter jaga, menurut peneliti, dipengaruhi oleh beberapa faktor lain seperti motivasi dokter tersebut untuk terus belajar, sumber informasi mengenai perkembangan ilmu terbaru serta kepercayaan dokter tersebut terhadap sesuatu.

\section{Hubungan lama kerja di IGD dengan tingkat pengetahuan dokter jaga IGD tentang tatalaksana henti jantung}

Lama kerja di IGD tidak memiliki hubungan yang bermakna dengan tingkat pengetahuan dokter jaga IGD tentang penatalaksanaan kasus henti jantung karena $p$-value yang didapatkan dari hasil statistik adalah 0,077 ( $p>0,05)$. Responden dikelompokkan menjadi dua kategori, yaitu lama kerja $\leq 3$ tahun (baru) dan $>3$ tahun (lama). Terdapat 38 responden yang masa kerjanya tergolong baru dan tingkat pengetahuannya didominasi dengan kategori baik $(63,2 \%)$. Sedangkan responden yang masa kerja $>3$ tahun sebanyak 6 orang, dan lebih dari separuhnya memiliki tingkat pengetahuan kategori cukup $(66,6 \%)$.

$\mathrm{Hal}$ ini tidak sejalan dengan pendapat yang dikemukakan oleh Notoatmodjo bahwa pengalaman merupakan salah satu faktor penting yang mempengaruhi tingkat pengetahuan seseorang. ${ }^{15}$ Berdasarkan teori tersebut, lama kerja di IGD akan mempengaruhi pengalaman seorang dokter jaga IGD dalam menangani kasus henti jantung. Semakin lama seorang dokter jaga bekerja, maka pengetahuannya tentang penatalaksanaan kasus henti jantung akan semakin baik. 
Menurut peneliti, tidak adanya hubungan antara lama kerja dengan pengetahuan dokter jaga IGD bisa saja terjadi karena jarangnya dokter tersebut menangani kasus henti jantung. Walaupun jumlah pasien yang ditanganinya sudah cukup banyak, namun jika tidak banyak yang mengalami henti jantung, maka artinya dokter jaga IGD tersebut kurang memperoleh pengalaman dalam melakukan tindakan penatalaksanaan terhadap pasien dengan kasus henti jantung.

\section{Hubungan Sertifikat ACLS dengan Tingkat Pengetahuan Dokter Jaga IGD tentang Tatalaksana Henti Jantung \\ Pada Tabel 5 tampak hasil uji statistik,} diperoleh $p=0,005(<0,05)$. Dapat disimpulkan bahwa ada hubungan yang bermakna antara sertifikat atau pelatihan ACLS yang telah diikuti dengan tingkat pengetahuan dokter jaga IGD tentang penatalaksanaan kasus henti jantung. Hasil penelitian ini menunjukkan dari 44 responden terdapat 33 orang yang telah mengikuti pelatihan ACLS dan lebih dari separuhnya memiliki tingkat pengetahuan yang baik (69,7\%). Sedangkan 11 responden yang belum pernah mengikuti pelatihan ACLS didominasi dengan tingkat pengetahuan yang cukup (45,4\%).

$\mathrm{Hal}$ ini sesuai dengan pendapat yang dikemukakan oleh Bart bahwa pelatihan merupakan upaya meningkatkan pengetahuan, mengubah perilaku dan mengembangkan keterampilan. ${ }^{16}$ Dan pelatihan merupakan suatu proses belajar mengajar terhadap pengetahuan dan keterampilan tertentu serta sikap agar peserta semakin terampil dan mampu melaksanakan tanggung jawabnya dengan semakin baik, sesuai dengan standar menurut Tanjung $\mathrm{H}$ dalam bukunya "Manajemen Motivasi". ${ }^{19}$

\section{Hubungan masa berlaku sertifikat dengan tingkat pengetahuan dokter jaga IGD tentang tatalaksana henti jantung}

Masa berlaku sertifikat ACLS memiliki hubungan yang bermakna dengan tingkat pengetahuan dokter jaga IGD tentang penatalaksanaan kasus henti jantung karena dari hasil statistik ditemukan nilai $p=0,032 \quad(p<0,05)$ dengan menggunakan uji Chi-Square. Dari Tabel 6 dapat dilihat bahwa responden yang memiliki sertifikat ACLS sebanyak 33 orang, 28 responden memiliki sertifikat ACLS yang masih berlaku dan didominasi dengan tingkat pengetahuan kategori baik (78,6\%). Dan terdapat 5 responden yang sertifikatnya sudah tidak berlaku, lebih separuhnya digolongkan kepada pengetahuan cukup.

$\mathrm{Hal}$ ini berkaitan dengan memori atau ingatan yang dimiliki oleh dokter jaga IGD. ${ }^{20}$ Ketika sertifikat ACLS masih berlaku artinya dokter tersebut baru saja mengikuti pelatihan tentang hal tersebut dalam tiga tahun terakhir, sehingga ingatan mengenai cara penatalaksanaan henti jantung masih baik. Sedangkan pada dokter jaga dengan sertifkat ACLS sudah tidak berlaku, ingatannya tidak sekuat yang sertifikatnya masih berlaku karena ia sudah melewati pelatihan ACLS lebih dari tiga tahun. ${ }^{23}$

Hasil penelitian ini didukung oleh pendapat yang diungkapkan oleh Bruno tentang memori atau ingatan. Menurut Bruno dalam Khadijah (2011), memori atau ingatan adalah proses mental yang meliputi pengkodean, penyimpanan, dan pemanggilan kembali informasi berupa pengetahuan yang semuanya terpusat dalam otak. Informasi tersebut akan masuk ke dalam memori jangka pendek untuk kemudian dikode dan suatu saat dapat di recall kembali. Sehingga semakin barunya tahun keluaran sertifikat maka semakin mudah memori tersebut di recall kembali. ${ }^{20}$ Dalam teori Aus (Disuse theory) disebutkan bahwa memori hilang atau memudar karena waktu. ${ }^{23}$ Oleh karena itu, dapat disimpulkan bahwa dokter dengan sertifikat ACLS masih berlaku memiliki tingkat pengetahuan yang lebih baik daripada yang sertifikatnya sudah tidak berlaku dikarenakan dokter yang baru mendapatkan sertifikat ACLS ingatannya akan jauh lebih baik dibandingkan dokter yang sudah lama mendapatkan sertifikat.

\section{Hubungan lulusan dengan tingkat pengetahuan dokter jaga IGD tentang tatalaksana henti jantung \\ Lulusan Perguruan Tinggi sebelumnya pada responden memiliki hubungan yang bermakna dengan tingkat pengetahuan dokter jaga IGD tentang penatalaksanaan kasus henti jantung karena dari hasil statistik dengan uji Chi-square menunjukkan $p=0,002$ $(p<0,05)$. Pada Tabel 7 menunjukkan terdapatnya 44}


responden, 36 diantaranya merupakan lulusan perguruan tinggi negeri dan sebagian besar memilki tingkat pengetahuan baik (66,7\%). Delapan orang responden merupakan lulusan perguruan tinggi swasta yang didominasi dengan tingkat pengetahuan buruk (50\%).

Ada beberapa hal yang mempengaruhi adanya hubungan lulusan dengan tingkat pengetahuan, seperti fasilitas dan mutu perguruan tinggi yang bersangkutan. Dalam teori Harsono menyatakan bahwa kualitas dosen PTS masih di bawah standar sehingga menjadi hambatan dalam peningkatan mutu pendidikan. ${ }^{[21]}$ Masih kurang lengkapnya fasilitas dan rendahnya kualitas dosen di perguruan tinggi swasta mempengaruhi kualitas dari lulusan perguran tinggi tersebut. Hal ini terkait dengan kemudahan para mahasiswanya dalam belajar. Ketika mereka tidak memperoleh fasilitas yang cukup, baik dari tenaga pengajar maupun peralatan, maka akan sulit bagi mereka untuk meningkatkan kualitas dari proses belajar mereka, dan hal ini akan berpengaruh kepada pengetahuan yang mereka miliki.

\section{SIMPULAN}

Kepemilikan sertifikat ACLS, masa berlaku sertfikat, dan lulusan mempengaruhi tingkat pengetahuan dokter jaga IGD dalam penatalaksanaan kasus henti jantung di rumah sakit tipe $\mathrm{C}$ di Sumatera Barat.

Umur dan masa kerja dokter tidak mempengaruhi tingkat pengetahuan dokter jaga IGD dalam tatalaksana kasus henti jantung.

\section{DAFTAR PUSTAKA}

1. Perhimpunan Dokter Spesialis Kardiovaskular Indonesia. Buku ajar kursus bantuan hidup jantung lanjut (ACLS). Jakarta: Perhimpunan Dokter Kardiovakular Indonesia; 2017.hlm.1-50.

2. Pusat Siaga Bantuan Kesehatan 118 Penanggulangan penderita gawat darurat (PPGD), basic trauma and cardiac support (BTCLS). Yogyakarta: Perhimpunan Rumah Sakit Indonesia Daerah Istimewa Yogyakarta; 2013.

3. American Heart Association. Part 4: CPR overview: American Hearth Association guidelines for cardiopulmonary resuscitation and emergency cardiovaskular care. AHA Journals. 2010;122 (4):676-84.

4. Goldbelger. Duration of resuscitation efforts and survival after in hospital cardiac arrest. An Observational Study. 2012;320:76- 84.

5. Departemen Kesehatan (Depkes) RI. Profil kesehatan Indonesia tahun 2006. Jakarta: Depertemen Kesehatan RI; 2007.

6. Neumar RW, Charles W, Mark S, Steven L, Michael S. Part 8 adult advanced cardiovascular life support 2010 American Heart Association guidelines for cardiopulmonary resuscitation and emergency cardiovascular care. Journal of the American Heart Circulation. 2010;(110.770913): 729-67.

7. Rumah Sakit Umum Elim Rantepao. Standar prosedur operasional dokter jaga dokter umum. Bandung: Rumah Sakit Umum Elim Rantepao; 2014.

8. Sekretariat Negara RI. Undang-Undang No.36 tahun 2014 tentang tenaga kesehatan. Jakarta: Sekretariat Negara RI; 2014.

9. Hidayati H. Standar pelayanan kesehatan pasien IGD di rumah sakit umum Abdul Wahab Sjahranie Samarinda (skripsi). Samarinda: Fakultas IImu Sosial dan IImu Politik Universitas Mulawarman; 2014.

10. Direktorat Jendral Pelayanan Medis Depkes RI. Prosedur pelayanan di instalasi gawat darurat (IGD) rumah sakit. Jakarta: Ditjen Kementerian Kesehatan Republik Indonesia Pelayanan Medis; 2006.

11. Sekretariat Jenderal Pusat Sarana, Prasarana, dan Peralatan Kesehatan. Pedoman teknis sarana dan prasarana rumah sakit kelas C. Jakarta: Depkes RI; 2007.

12. Indonesia Case Base Groups. Syarat rumah sakit umum tipe C. Informasi INA CBGs, BPJS, JKN dan Kesehatan Indonesia (diunduh 4 Nopember 2017). Tersedia dari: http://inacbg.blogspot.co.id/2015/ $\underline{05 / \text { syarat-rumah-sakit-umum-tipe-c.html. }}$.

13. Knoers AM, Hadinoto SR. Psikologi perkembangan: pengantar dalam berbagai bagian. Yogyakarta: Gajah Mada University Press; 2004. 
14. Handoko $\mathrm{H}$. Manajemen personalia \& sumber daya manusia. Yogyakarta: Bhakti ProfesindoYogyakarta; 2010.

15. Notoatmodjo S. Pendidikan dan perilaku kesehatan. Jakarta: PT. Rineke Cipta; 2003.

16. Bart S. Psikologi kesehatan. Jakarta: Grasindo; 2004.

17. Departemen Kesehatan RI. Kategori umur. Jakarta: Depkes RI; 2009.

18. Ifada I. Faktor-faktor yang berhubungan dengan pengetahuan masyarakat mengenai pelayanan kesehatan mata (skripsi). Semarang: Fakultas Kedokteran Universitas Diponegoro; 2010.
19. Tanjung $H$. Manajemen motivasi. Jakarta: Gramedia Widia Sarana Indonesia; 2003.

20. Khadijah N. Psikologi Pendidikan. Palembang: Grafika Telindo Press; 2011.

21. Harsono. Pengelolaan perguruan tinggi. Yogyakarta: Pustaka Pelajar; 2008.hlm.295-309.

22. Maulana H. Promosi kesehatan. Jakarta: Penerbit Buku Kedokteran EGC; 2007.

23. Perhimpunan Dokter Kardiovaskuler Indonesia. Advanced Cardiac Life Support Indonesia. Kursus ACLS Indonesia [serial online] 2013 feb (diakses 2 februari 2018). Tersedia dari: http://www.aclsindonesia.com/index.php/public/information/announ ce-detail/ 